\title{
Global History, Geography and the Classics
}

\section{Carla Bocchetti}

\section{OpenEdition \\ Journals}

\section{Electronic version}

URL: https://journals.openedition.org/eastafrica/311

DOI: 10.4000/eastafrica.311

ISSN: 2790-1076

\section{Publisher}

IFRA - Institut Français de Recherche en Afrique

\section{Printed version}

Date of publication: 1 March 2016

Number of pages: 7-18

ISSN: 2071-7245

Electronic reference

Carla Bocchetti, "Global History, Geography and the Classics", Les Cahiers d'Afrique de I'Est / The East African Review [Online], 51 | 2016, Online since 07 May 2019, connection on 09 December 2021. URL: http://journals.openedition.org/eastafrica/311 ; DOI: https://doi.org/10.4000/eastafrica.311 
Introduction

\section{Global History, Geography and the Classics}

Carla Bocchetti

"He [The Roman Masai] had great poise and dignity and seems to be very intelligent."

(Ernest Hemingway, The Green Hills of Africa).

The purpose of this volume is to instigate a new dialogue involving studies of 'global history', Africa and the Classics, as so far the Classics have been left out from recent advances in global history. The aim is to expose Classics to contemporary preoccupations about the use of the past in global history, whereby Classics begins to lose the privileged position it has enjoyed within European imperial culture. Africa has been chosen as the case study to illustrate not only the hybridity of the Classical past, but also the collapse of the model of the Classics as 'universal history'. As such, the volume encompasses a list of contributions that are rarely seen together in a publication related to Classical history ${ }^{1}$. The relativisation of Classical history, no longer conceived of as the epitome of civilization ${ }^{2}$, provides an opportunity to deconstruct imperial epistemologies founded in/inspired by the ancient Classical world.

Scholars who work in global history have spent a lot of time clarifying what global history is not. It is not world history, or universal history, it is not national history, nor simply comparative history ${ }^{3}$. So, what is global history? In recent work by Gerritsen and Riello focusing on global history, predominance is given to artifacts as a new way to narrate history through objects: "the way in which artifacts came to be powerful tools for the creation of global connections" 4 . They further argue that "the global turn transformed the way in which historians studied objects. They began to see the connected histories that led to the circulation of objects throughout the various parts of the world" ${ }^{5}$. In spite of their emphasis on the circulation of objects and their consumption, neither Classical ruins, nor ruins in general, have constituted part of Gerritsen and Riello's investigations, and there is no a single article in their collected editions devoted to these phenomena.

Although the recent book by McNeil and Riello ${ }^{6}$ deals with the historical development of the idea of 'luxury' including Antiquity, their approach lacks an emphasis on the global connections of the Classical world as reformulated through European imperialism, and the broader epistemological positions these underwrote.

\footnotetext{
${ }^{1}$ This volume is related to the project « Globafrica » Reconnecter l'Afrique: l'Afrique subsaharienne et le monde avant l'impérialisme européen. ANR - USR 3336 http://globafrica.hypotheses.org. I want to thank colleagues and friends that supported this work at different stages: Dr. Marie Emmanuelle Pommerolle, Dr. Sylvain Racaud, Dr. Christian Thibon, Emma Park, David Kay and the team at UN Volunteers.

${ }^{2}$ Peter F. Bang, The Roman Bazaar: A Comparative Study of Trade and Markets in a Tributary Empire (Cambridge University Press, 2008).

${ }^{3}$ David Washbrook, Problems in Global History. In Writing the History of the Global, ed. by Maxine Berg (Oxford University Press, 2013).

${ }^{4}$ Anne Gerritsen and Giorgio Riello, Introduction. InWriting Material Culture History, ed. by Anne Gerritsen and Giorgio Riello (Bloomsbury, 2015), p.6.

${ }^{5}$ Anne Gerritsen and Giorgio Riello, Introduction. In The Global Life of Things, Material Culture in the First Global Age, ed. by Anne Gerritsen and Giorgio Riello (Routledge, 2016), p.13.

${ }^{6}$ Peter McNiel and Giorgio Riello, Luxury: A Rich History (Oxford University Press, 2016).
} 
This special issue of Les Cahiers d'Afrique de l'Est aims towards remodeling a 'globalised Classicism' as a form of material culture within global history studies, and to ask how these guiding themes might open up new questions regarding Classical Antiquity, Africa and the 'modern'.In order to do so, it is necessary to revisit some traditional views of the Classics and frame them within a global historical perspective. In this regard, the approach of this volume works with two main themes:

1. Global history revaluates the way in which historians deal with the past. In this sense it represents a challenge for Classics to instigate a dialogue with other disciplines to which it is not normally related.

2. Global history works with the preconception that movement in space forms the bases for connectivity and consumption patterns, yet to date geography has not been placed at the center of global historical studies.

The volume aims, firstly, to contribute to an opening up of a space for Classics in global history, considering Classical ruins as a globally relevant form of material culture, and secondly, to explore the way in which Classical Antiquity has been universally consumed not just as a European commodity, but as a hybrid global product, and finally, to address the role of Africa in contesting the supremacy of Classics as universal history.

\section{Ruins and Imperial Identities}

I would like to offer some suggestions as to how global historical approaches can open up new questions regarding Antiquity and the place of Africa ${ }^{7}$ in genealogies of 'the modern'. As this volume hopes to show, global historical approaches suggest new avenues of exploration that transcend a Eurocentric reading of the Classics as the pillar of universal history, and which might therefore transcend some of the limitations of earlier approaches, mainly those which privileged time (history) over space (geography) ${ }^{8}$ (see Carla Bocchetti, this volume).

By Classical Antiquity I mean both the physical remains of the ancient Graeco-Roman world and also subsequent discourses concerning these remains; a rhetorical construction that draws a direct line between a limited reading of Classical Antiquity and the foundation of the Western world. I will develop the idea of Classics as a global product in order to show that ruins, together with geography, allow new ways of reading the past; reevaluating the privileged position that Classics have played in European history. First, however, let me begin by exploring how Classical Antiquity became linked to notions of European superiority.

Since the 18th century, Classical Antiquity has been reserved for Europe; the cornerstone of an elite education in imperial identity.

\footnotetext{
${ }^{7}$ Patrick Manning, "Africa and World Historiography”, The Journal of African History 54 (2013): 319-330.

${ }^{8}$ On the debate of modern theories of geography, history and the classics see Katherine Clarke, Between Geography and 
This education took many forms. Consider, for example, the Romantic movement, exemplified by Goethe and Winckelmann", which considered the nobility and simplicity of ancient Greek art a model of artistic perfection. Or Grand Tour travelers, like Byron and other Englishmen, who moved through Classical lands in order to complete their self-education by visiting ancient ruins. Or the French scholar Volney, who drew a direct line between past and present; linking the political organization of Classical Athens to the European political states of the 18th century. As these examples suggest, 18th century European intellectuals drew on the cultural formations of Antiquity to consolidate emergent notions of European cultural hegemony. By the 19th century, intellectuals were drawing on the cultural legacy of Antiquity to bolster an emergent discourse of European superiority which legitimized the mission of empire. In doing so, Victorians reframed the unfolding of history, claiming a direct lineage from the glories, cultures and politics of ancient Greece to 19th century European states. Through this process, ancient Greece was framed as the progenitor of 18th-19th century white European 'civilization'. This is the period when major collections of Greek and Roman art were begun, and the beginning of the foundation of large national museums in Europe. As such, the ruins of Classical Antiquity formed (and continues to form) an integral part of the foundational stories of the modern West.

\section{Classical Antiquity as a Global Commodity}

Global history pays a great deal of attention to spatial relationships and horizontal connections, and therefore geography, and the social networks these create, can explain much more about the world in which we live today than history alone. On the other hand, the emphasis global history places on material culture supports an interpretation of ruins and antiquities as trade commodities of empire (like cotton for instance) ${ }^{10}$, and therefore that objects from the Greek and Roman past have played a decisive part in the construction of the idea that there is a cultural predisposition that made Europe and North America richer and better and the rest of the world (the 'Great Divergence') (see Riello, this volume).

During the 18th and 19th centuries, fragments of antiquities, as well of copies of arches, columns, pediments and other monuments, emerged as symbols of democracy and civility. By the 19th century, the so-called economic exceptionality of Britain's industrial revolution was accompanied by the selective use of the materials of Classical Antiquity. In other words, throughout the period of 'the long 18th century' ruins were transformed into global commodities: symbols of western hegemony and superiority erected and consumed around the globe.

In this way, the objects of the Classical past were transformed into a discourse of genuine European product. As the archeological record of Classical Antiquity was reframed as the model of the modern, so Classics became the reference for understanding other peoples' pasts. In the field of archeology, for example, archaeological zones around the world were explained in reference to Classical Antiquity.

\footnotetext{
${ }^{9}$ Simon Goldhill, Victorian Culture and Classical Antiquity: Art, Opera, Fiction and the Proclamation of modernity (Princeton University Press, 2011).

${ }^{10}$ Giorgio Riello, Cotton: The Fabric that Made the Modern World (Cambridge University Press, 2013).
} 
Places with no Classical heritage were considered barbaric, as spaces at the periphery of civilization, or even inauthentic when original Classical references were found outside Europe. In other words, the Classical, as a discourse based on material foundations, can in part be defined by its exclusionary impulse.

As the foregoing suggests, global history provides tools that can help us move between the hybridity of the Classical world itself and the global nature (and subsequent critique) of the imperial Western epistemologies which drew on both physical and imagined Classical material. In what follows, I explore how global historical approaches, which understand historical processes as a series of relations, might open up new avenues of inquiry. If the world viewed through the lens of global history is made flat, then horizontal and geographical models become especially relevant for the understanding of these connections. In this way, global history can offer a revision of traditional epistemological approaches to Classical Antiquity, in which Greece becomes just another place in the Mediterranean world, rather than the ideal topos of Western exceptionalism. This reframing is in line with several important questions: How might the past be re-enacted if we break the dialectic of centerperiphery? How might a multi-centric reading of the past challenge our notions of history, displacing as they do questions of origin? How might the introduction of geography to historical analyses challenge some well-known historical preconceptions? And what other pasts might become visible as Classical Antiquity is backgrounded and, subsequently, Europe itself is provincialised?

With these questions in mind we will explore the classical past as a hybrid global product. Despite a common academic emphasis on mobility and diaspora, movement and space are often deployed as metaphors rather than categories of analysis in their own right. It is through this ambivalence that global history has something novel to offer, which brings us to divergence theories. While Classical Antiquity was used to shore up nationally-founded imperial identities, the divergence debate has challenged historians to think outside their national boundaries and to consider histories of relationality that predate European industrialization, therefore confronting the legitimisation of the use of the Greek and Roman past as universal history.

As noted by critics, divergence theory creates asymmetries in how we narrate history. According to Schaub ${ }^{11}$, asymmetry is defined as the differential between diverse societies in their capacity to be influential one another. Central to academic studies of Africa conducted along these lines is a mode of analysis that emphasizes how Africans saw themselves in the world, as opposed to the categories that empire imposed upon them.

Working with some of these insights, global historians have redefined the ancient Mediterranean as a space of cross-cultural connections. In the peripheries, if we follow the vertical model imposed by the historical discourse, Classical Antiquity plays the ambivalent

${ }^{11}$ Jean Frédéric Schaub, Notes on some Discontents in the Historical Narrative. In Writing the History of the Global, ed. by Maxine Berg (Oxford University Press, 2013), p.51. 
role of both status quo and subversive element. This means that the past is performed and perceived in a variety of forms when it loses its tight connections to the center ${ }^{12}$.

Classical ruins play a part in global history as a distinctive form of material culture, for example in informing the national discourses of independent nations. To what extent we can say that ruins are global objects? The modern Greeks have revaluated their Classical past, and in this process archaeological ruins have played a decisive role in revising colonialism and shaping modernity ${ }^{13}$. However, these ruins (and their models/replicas) have also travelled, influencing global encounters and establishing dialogues with local histories, even if as a mode of erasure. In other words, the landscape of ruins - fragments and broken objects of the Classical world - has formed a critical part of how modernity has been defined and constructed ${ }^{14}$.

Classical ruins are also the subject of consumption, reproduction and forgery, a taste for which developed together with imperial culture. Seizing the past was a means of conferring authority and prestige upon the practitioners of the imperial project. Although objects can open up the history of private lives, the interior of houses and everyday practices, they also reveal transnational patterns of contacts and perceptions of remote lands. Classical ruins are appropriated by nation states and therefore they bring a collective symbolism to society in terms of national enterprises ${ }^{15}$.

Classical ruins, travelling as objects of collection, have also played a key role in the formation of museums. However, ruins transcend the private aspects of collecting, as most archaeological sites are available to public eyes. Although the Parthenon and other monumentally impressive archaeological sites have often been used to tell the stories of those in privileged positions, Classical ruins can also be employed to tell the stories of common people or peripheries. As with Chinese porcelain or cotton, Classical ruins as a form of material culture can reveal both private and public lives, trans-oceanic connections, designs, taste, collecting and consumption, and as self-contained objects they communicated, and indeed fashioned, the identities of the people who owned, used and viewed them.

\footnotetext{
${ }^{12}$ In the peripheries, the discourse of the Classical past played the opposite role. It acted as an underground discourse that supported political revolutions and cultural transformations. Phiroze Vasunia, The Classics and Colonial India (Oxford University Press, 2013.), p.27, and Barbara Goff, 'Your secret language': Classics in the British Colonies of West Africa, Classical Diaspora (Bloomsbury Academic, London 2013), examines the ways in which European colonisers and African nationalists clashed, or collaborated, over the uses of Latin, Greek and the Classics. See also Emily Greenwood, AfroGreeks: Dialogues Between Anglophone Caribbean Literature and Classics in the Twentieth Century (Oxford University Press, 2010). Carla Bocchetti, Neoclassical Pompai in 19th Century Latin America. In Buen Gusto and Classicism in the Visual Cultures of Latin America (1780-1910), ed. by Paul Niell and Stacie G. Widdifield (New Mexico University Press,2013); Carla Bocchetti, La Geografía de la Iliada: Un Proyecto Cultural (Universidad Nacional Autónoma de México, 2011).

${ }^{13}$ Yannis Hamilakis, The Nation and its Ruins: Antiquity, Archaeology, and National Imagination in Greece (Oxford University Press, 2009).

${ }^{14}$ See the concept of ruination in Ann L. Stoler, Imperial Debris: on Ruins and Ruination (Duke University Press, 2013), p.195 where the idea of ruins in general are explained as embers of empire attached to conflict, political domination and destruction.

${ }^{15}$ Maya Jasanoff, Edge of Empire: Lives, Culture, and Conquest in the East 1750-1850 (Vintage Books NY, 2005), pp.6,113.
} 
In this respect, global history opens up not just the matter of reclaiming Classical discourses for the world outside of Europe, but also demands a scholarly awareness that the ancient past of Greece and Rome, reconfigured as universal history, was integral to the cultural vehicle of empire.

The so-called 'Greek miracle', together with the perceived exceptionality of European culture, has to be continuously revisited in the light of contact and influence from other cultures; Classical Antiquity should be seen as just another example of cultural hybridity in a world of filled with spatial modes of connection.

In order to address the issues and themes outlined above, the contributions to this volume have been divided into three parts: 1) Classics and Africa; 2) Global History and Geography; and, 3) Visual Culture and Africa.

\section{Section 1. Classics and Africa}

The publication of the book African Athena in 2011 raised questions about the idea of the nation, national identity and belonging. In particular, using the lens of postcolonial studies, it called for a revisionist view of the role of Africa in the construction of Western modernity, and directed attention to how paths of migration and diaspora have been entangled within the social construction of transnational relationships. These questions also form the basis of global history studies.

African Athena was inspired by Martin Bernal's Black Athena. Published in 1987, Bernal's polemic work drew attention to the exclusion of African and Asiatic influences from academic approaches to Classical civilization. If Africa has long been seen as a historical entity only in its relation to European empires, African Athena placed Africa in the center of formations of the 'modern'. There is a strong critique of the way in which Africa had previously been set in dialogue with the discourse of Classicism, but there is an even greater emphasis on the absence of that dialogue. African Athena queried the implications of the West's underestimation of African contributions to Classical culture, and thus generated a critique of the Eurocentric construction of Classical history.

While African Athena has done an admirable job of documenting through literary sources the influence of Africans living in the diaspora and their role in shaping modernity, it left a gap in relation to material culture that global history can fill through the study of archaeological sites, ruins and antiquities.

The first section of this volume makes manifest that through global historical studies, Africa becomes a stronger player in its dialogue with Antiquity. The paper by Vasunia - "Ethiopia and India: Fusion and Confusion in British Orientalism" - demonstrates how colonial views of 'the Orient' were grounded in references to Greece and Rome, as well as targeting the elusiveness of remote geographical locations within imperial projects. The early colonial confusion of India and Ethiopia is shown to extend back to Antiquity. "Ethiopia" seems to be a name used to denote any region in the far South, mostly "India" but also any other 
region in the whereabouts of Africa, Arabia and south Asia. For Vasunia, the conflation took deeper root in the 18th century as part of Orientalists' fascination with skin color, race and slavery; well before these spaces were defined by modern national limits. Through the writing of William Jones and Francis Wilford, two British colonial administrators in Bengal, Vasunia explores the Enlightenment universalism in which both writers were embedded. For Jones, India and Africa were connected by architectural, linguistic and racial lines, whilst Wilford drew comparisons between their geographies and etymologies. This article shows that new realities formed during the colonial project referred back to Classical Antiquity, in order to assimilate the heterogeneous into European metanarratives of universal history and geography.

If Ethiopia and India were conflated during the pre-colonial and colonial periods, Africa as a wider entity was largely reinvented through Classical myths. Theories of Africa after colonisation were articulated through the use of Greek myth, or else its explicit rejection. This is the subject which Orrells addresses in his article - "V.Y. Mudimbe and the Myth of Oedipus". For Orrells, the notion that Oedipus's story is universal exemplifies the history of Eurocentric thought, which continually and imperialistically applied its own logic and categorisations onto colonial subjects. Orrells argues that the myth of Oedipus has been used in African philosophy as a foundational story for the 'murder' of the colonial 'father', and explains that V.Y. Mudimbe considers Oedipus to have become an important metaphor for trying to articulate the nature of the relationship between the civilized and the savage, and by extension the foundation of the state. He also argues that at the base of Mudimbe's work there lies a preoccupation with how valid it is to study Africa using Western methodologies, and that colonialism itself has therefore produced a dangerous oedipal relationship between the coloniser and the colonised.

\section{Section 2. Global History and Geography}

Section Two deals with theories of global history, and the importance of placing geography at the center of global historical investigations. All three articles in this section draw attention to how Classical discourse (and practice) was foundational to many phenomena of European imperialism, from industrialisation to cartography. However, they also subvert such perspectives by showing how these same material phenomena (cotton/maps) can actually be used to open up wider global histories which disrupt Classically-inspired European triumphalist narratives and methods of control. In this regard, history and geography unite to suggest new interpretations of the use of the Classical past; both what it occludes and what it can thus signpost for renewed scholarly attention.

In his contribution to this volume, Riello challenges the idea of European exceptionality and narratives of triumphalism, explaining how contacts between Europe and other places, mainly India, enabled the cotton-based industrial revolution in Europe. In this way he addresses a central question of global history: "why did Europe get richer that the rest of the world?" For Riello, it was a long term process spanning over two centuries, in which Europe acquired local knowledge from others. 
Geography and the dynamics of space come into play as the bases of Riello's investigation, in how space plays a part in patterns of contact, consumption and technology transfer. Although his research focuses on cotton, his methodology addresses (explicitly or implicitly) many other issues, for instance the question of how global history can challenge our ideas of the past, especially those tied to European triumphalist history, i.e. Graeco-Roman Antiquity. As Riello explains, the new global system created by cotton also brought other artifacts at the base of consumption patterns into imperial culture. Many items commonly included in global trade, such as tea, sugar and tobacco from the plantations, as well as Chinese porcelain, folding screens, pineapples and other exotic luxury items, travelled alongside a passion for Classical ruins, whereby the material culture of the past - whether original or reproduced (as with pottery, statues, columns and other architectural items) was circulated throughout vast areas of the world and consumed in many remote geographical locations. Contemporary approaches to studying geography open up new ways to respond to old issues, reconsidering notions of triumphalist European history in which space became tamed through the process of mapping, which subsequently influenced Western cultural notions of what Africa is. In this respect, geography and cartography offer valuable epistemological approaches to global history.

Bocchetti's article studies the depiction of Africa in Early Modern European maps in order to create an awareness of the importance of 'place and space' within global historical investigations which extends beyond the frame of the nation-state. By comparing Arab and European maps and manuals to African conceptions of space, Bocchetti revaluates the view of Africa as an unknown and dark continent circulating in early Modern Europe. She argues that despite the absence of Swahili written records and drawn maps, their knowledge must have informed the geographical corpus of other communities, playing a substantial role within the written culture and cartographic tradition of the wider Indian Ocean world. The article focuses on discussing cartography as a means of ordering unknown worlds and thus coming to control them, but subverts this role by looking at what knowledge (and its 'indigenous' sources) underlay such strategies. The interplay between Arab and European maps in expansionist projects also makes us reconsider the ways in which Classicallyinspired perspectives have incorporated these two traditions.

Pollard's article is an account of Southeast Tanzanian ports and landings as recounted in 19th century European maps, with an aim to demonstrating how these littoral areas are in need of increased archaeological investigation. Landscape modification in terms of coral causeways seems particularly interesting, as does the evidence that smaller sites (as opposed to large well-known stonetowns such as Kilwa) were of crucial importance to early European shipping, for example for taking on fresh water. European cartography stemmed from a Classical epistemological background and was a key tool of European domination leading to colonialism, yet these particular charts subvert such a narrative by demonstrating the wide range of relatively small-scale Swahili sites which European sailors were actively dependent upon in order to successfully ply these coastal routes. They also highlight the materiality/morphology of the coastline which shaped these interactions and which now beckons us to return to the study of such physical features in an effort to place the academic 
emphasis back on the Swahili's own experiences of their littoral/maritime environments.

\section{Section 3. Visual Culture and Africa}

The popularity of collecting marked the era of British colonial enterprise by projecting imperial identities onto foreign objects. Most of the objects were placed beyond local histories or origins, becoming key components of colonial language and practices ${ }^{16}$.

In the case of Greek antiquities, ancient Greece was constructed as an idealized place remote from the modern Greek nation from which these antiquities were sourced, and so Classical Antiquity became an abstract construction of no inherent location. It was rhetorically constructed as the idealized origin point of Western culture ${ }^{17}$, as epitomised by the European Neoclassical style of art and architecture; believed to encapsulate good taste and erudition, an example of 'virtue and enlightenment'.

The four papers that comprise this section address Classical influences in the colonies, creating a dialogue with other influences stemming from cultures in East Africa, AfroCuba, South Asia and the wider Indian Ocean world.

The article by Niell entangles the worship of ceiba trees by the African-American community of colonial Cuba with the Neoclassical buildings of the island, especially El Templete; a building erected to replace a large ceiba tree and commemorate the foundation of Cuba as a Spanish colony. Niell's arguments concerning historiography and the 19th century reimagining of Havana's past informs his discussion of subaltern voices as co-opted within dominant narratives, in this case in the context of slavery. He further points out that the importance of the ceiba tree as a source of 'aché' is already a re-figuration of landscape through West African memories. His discussion of El Templete thus creates a sense of place in a politically turbulent time for the colonial authorities themselves in regards to their relations with the Spanish Crown, and a complex subaltern landscape comprising many different cultural expressions, albeit within a greatly unequal social and political context.

Kaufmann's article refers to the curation of the exhibition "Patterns of Contact: Designs from the Indian Ocean world" at the Iziko South African National Gallery upon the occasion of Cape Town being selected as the 2014 World Design Capital. As a curator with an interest in early colonial history and archaeology, Kaufmann created an opportunity to showcase some of the lesser known objects held by the Museum and place them in dialogue with objects from other local collections. This made it possible for visitors to view historic works of art, rare maps, furniture, porcelain, silver, textiles and marine relics which had never been exhibited together before. Most of the objects displayed derive from European-driven collecting efforts, whilst the exhibition's section on cotton in particular relates to European consumption of 'the Other's' designs and knowledge (see also Riello, this volume).

\footnotetext{
${ }^{16}$ Thomas Nicolas, Entangled Objects: Exchange, Material Culture and Colonialism in the Pacific (Harvard University Press, 1991).

${ }^{17}$ Katherine Harloe, Winckelmann and the Invention of Antiquity (Oxford University Press, 2013).
} 
The article also tackles the construction of new cosmopolitan histories that subvert older Euro-centric narratives and material assemblages, and indeed the foundation of institutions to house (and regulate access to) them. This exhibition has helped to re-assess such institutions by bringing together objects that wouldn't normally be displayed together, with the explicit aim of depicting the complex, globally connected, and sometimes uncomfortable histories, that comprise modern Cape Town.

Longair discusses the use of Neoclassical architecture in the early colonial urban landscapes of Zanzibar and Nairobi. Her research is informed by migration and influence from around the Indian Ocean and the dialogue established through the use of Sarracenic architecture for British colonial buildings. She focuses on the figure of John Sinclair, a British administrator-architect in East Africa from the early 1900s. Longair's intent is to illuminate the many competitive factors which contributed to the deciding of the formal style for colonial buildings, which related not only to European traditions but also to influences from India and the Arabic world.

Omenya's article studies the migration of South Asians into Kisumu in the interior of Kenya. He explores the visual culture of South-South relations, and his focus on trade renders objects as active agents in the creation of social relations and the modification of the urban landscape. The activities of objects and shops are thus enrolled in the projection of public identities within Kisumu, where South Asian merchants first settled in 1905. These merchants greatly transformed the consumer habits of local inhabitants through the introduction of such exotic wares as clothes, blankets, oil, salt, sugar and tea. Furthermore, the Neoclassical ex-colonial buildings that South Asian migrants have occupied tells a story of the members of a colonially-privileged economic class who have physically surrounded themselves with the architectural fabric of the old political order, in an interesting example of the lasting continuity of Classically-inspired expressions of social hierarchy in a post-colonial context. Overall, Omenya's article can be seen as a reaction against the homogenization of identity within discourses of ideology and power ${ }^{18}$, and works toward establishing less fixed means of interpreting cross-cultural encounters.

\section{Conclusion}

Classical forms, whether in themselves as collected objects or as reconfigured styles (e.g. Neoclassicism), have travelled across the world through a series of global engagements, of which European imperialism has been the most notable. This engages with Riello and Gerritsen's discussion of the physical movement of goods/objects and how their meanings (and in some cases physical forms) have undergone revision en route. This special edition of Les Cahiers d'Afrique de l'Est aims to point out that Classical remains/motifs can be seen as mutable cultural objects whose trajectories have been deeply imbricated with specific social encounters. Classical remains have had a huge influence on Western thinking, epistemologies, and indeed ontologies of contact, exchange and power. The Classical foundation of Western thought has been 'hybridised' not only through changes in the West but also the global circulations through which it has travelled.

${ }^{18}$ Sofaer Joanna, Introduction. In Material Identities, ed. by Joanna Sofaer (Blackwell Publishing, 2007), p.3. 


\section{Bibliography}

Bang, F. Peter. The Roman Bazaar: A Comparative Study of Trade and Markets in a Tributary Empire. Cambridge University Press, 2008.

Bocchetti, Carla. "Cultural Geography in Homer." Eras Journal, Monash University, Australia. http://arts.monash.edu.au/publications/eras/edition-5/bocchettiarticle.php La Influencia Clásica en America Latina. Universidad Nacional de Colombia, 2009. La Geografia de la Ilíada: Un Proyecto Cultural. Universidad Nacional Autónoma de México, 2011.

Neoclassical Pompai in 19th Century Latin America. In Buen Gusto and Classicism in the Visual Cultures of Latin America (1780-1910), ed. by Paul Niell and Stacie G. Widdifield, New Mexico University Press, 2013.

Clarke, Katherine. Between Geography and History: Hellenistic Constructions of the Roman World. Oxford University Press, 1999.

Gerritsen, Anne and Giorgio Riello . Introduction. In Writing Material Culture History, ed. by Anne Gerritsen and Giorgio Riello. Bloomsbury, 2015.

Introduction. In The Global Life of Things, Material Culture in the First Global Age, ed. by Anne Gerritsen and Giorgio Riello. Routledge, 2016.

Goff, Barbara. 'Your Secret Language': Classics in the British Colonies of West Africa. Classical Diaspora. Bloomsbury Academic: London, 2013.

Goldhill, Simon. Victorian Culture and Classical Antiquity: Art, Opera, Fiction and the Proclamation of modernity. Princeton University Press, 2011.

Greenwood, Emily. Afro-Greeks: Dialogues Between Anglophone Caribbean Literature and Classics in the Twentieth Century. Oxford University Press, 2010.

Hamilakis, Yannis. The Nation and its Ruins: Antiquity, Archaeology, and National Imagination in Greece. Oxford University Press, 2009.

Harloe, Katherine. Winckelmann and the Invention of Antiquity. Oxford University Press, 2013.

Jasanoff, Maya. Edge of Empire: Lives, Culture, and Conquest in the East 1750-1850. Vintage Books NY, 2005.

Joanna, Sofaer. Introduction. In Material Identities, ed. by Joanna Sofaer. Blackwell Publishing, 2007.

Manning, Patrick. "Africa and World Historiography", The Journal of African History 54 (2013): 319-330.

McNiel, Peter and Giorgio Riello. Luxury: A Rich History. Oxford University Press, 2016.

Riello, Giorgio. Cotton: The Fabric that Made the Modern World. Cambridge University Press, 2013.

Thomas, Nicolas. Entangled Objects: Exchange, Material Culture and Colonialism in the 17 Pacific. Harvard University Press, 1991. 
Schaub, Jean Frédéric. Notes on some Discontents in the Historical Narrative. In Writing the History of the Global, ed. by Maxine Berg. Oxford University Press, 2013.

Stoler, L. Ann. Imperial Debris: on Ruins and Ruination. Duke University Press, 2013.

Vasunia, Phiroze. The Classics and Colonial India. Oxford University Press, 2013.

Washbrook, David. Problems in Global History. In Writing the History of the Global, ed. by Maxine Berg. Oxford University Press, 2013. 